\title{
Integration of Nationalistic and Religious Values in Islamic Education: Study in Integrated Islamic School
}

DOI: https://doi.org/10.47175/rissj.v1i3.108

\author{
${ }^{1}$ Department of Islamic \\ Education, Universitas Alma \\ Ata, Yogyakarta, Indonesia \\ ${ }^{2}$ Department of Education \\ Management, Universitas \\ Ahmad Dahlan, Yogyakarta, \\ Indonesia
}

| Akhsanul Fuadi $^{1}$ | Suyatno ${ }^{2 *}$ |

*suyatno@pgsd.uad.ac.id

\begin{abstract}
The education that integrates nationalistic and religious values expected to transform the student to be good citizens and God' obedient servants. This research aims to explore two purposes: first, what is the purpose based on the integration of nationalistic and religious in learning in Integrated Islamic School; second, how is the teacher's strategy in Integrated Islamic School in integrating nationalistic and religious in learning conducted. This research is qualitative research with case study approach. The data was taken from the interview of seven teachers in Integrated Islamic School of Yogyakarta Region from primary school to secondary school and documentation. The data collected was analyzed by interactively inductive data analysis technique of Miles and Huberman model consisting of data collection, data reduction, data display, and conclusion withdrawal. The finding of this research showed that; first, the integration of nationalistic and religious values was conducted based on the ideal Indonesian human concept that is the obedient human of Indonesian towards the state in which the main indicator is nationalism also the obedient human of Indonesian towards God in which the main indicator is religious soul. Second, the integration of nationalistic and religious values conducted through three main strategies, namely; integration in curriculum, co-curriculum, and extraculliculer; internalization of nationalistic and religious values; and habitual activity of nationalistic and religious values in the school culture. The finding of this research can be used as reference for teachers in implementing the strategy in integrating nationalistic and religious values to students.

KEYWORDS

Ideal Indonesian Human; nationalistic; religious; integration; integrated islamic school.
\end{abstract}

\section{INTRODUCTION}

As the country with the largest Muslim population in the world, Indonesia has the opportunity to present itself as the international world model on how Islam and Indonesia can align and along with. It emphasizes the effort from various parties to sit together in order to have the same understanding and awareness about the importance of uniting Islam and Indonesia so that it creates a Rahmatan Lil Alamin civilization. Alkatiri (2017) mentioned that the lack of shared awareness often leads to tensions toward the relationship between Islam and Indonesia, a relationship that complicates the future due to the gravity in an antagonistic direction. The education and learning process in school still needs to be revitalized because Pancasila values as one of the main competencies that students must possess have not been fundamentally implemented (Silalahi \& Yuwono, 2016). Added by globalization flows, the challenges of 
Indonesia's nationalism are growing heavier (Aspinall, 2016; Bourchier, 2019; Sulistiyono, 2018; Thoriquttyas \& Rohmawati, 2017). Therefore, Indonesia needs to equip the future generation with an attitude of life that can integrate Islam and Indonesia in one harmonic frame. Therefore, nationalistic and religious values need to obtain an emphasis in the educational process in school. By nationalism, someone will have love and proud of Indonesia (Supratno, 2019) and also with religious values someone will have the obedience toward the laws of God as well as as the foundation of the character to face the various challenges as the impact of technology and information development.

The previous researcher researched instilling nationalistic and religious values. Ismawati (2018) researches about the nationalistic elements in the Indonesian language subject. The results of this research showed that Indonesia's literature work consists of many values of nationalism. According to the research findings, the researchers recommend the need for nationalism instruction that is easy to digest to embody the character of nationalism among the students. Meanwhile, Komarudin et al. (2019) analyze the implementation of the national education model by using SCORE-A (the abbreviation from Spatial Awareness (SA), Culture Awareness (CA), Organization Awareness (OA), Religion Awareness (RA), and Economic Awareness (EA)).

The results of the research showed that the SCORE-A model could improve nationalistic values so that they are more in love and proud of their state though they come from different religions, ethical, and linguistic backgrounds. Except for the three types of research above, the other researches focus on how the subject, strategy, and individual media can be used as a facility to increase nationalistic and religious values. For instance Muzayanah (2017) researches the role of Islamic education and local tradition in strengthening student's nationalism. The results of the research mentioned that three teaching materials in Islamic education strengthen nationalism, namely democratic, unity, tolerance, and harmony. Nurdin's finding (2015) explained that citizenship or civic education in Indonesia is held separately through a particular subject, namely "civic education." Civic education aims to form citizenship to have a spirit of nationalism and patriotism. However, Susanto and Suntoro (2018) researched about the internalization of nationalistic values in civic education. They conclude that civic education has successfully instilled nationalistic value with value transformation indicator, value transaction, and nationalistic value trans-internalization in students. The other related research, for instance, is how the education in Islamic Boarding School can improve student's nationalism (Abdurrahim, 2016), implement telling story method to increase nationalistic attitude (Putri \& Yuli, 2017), adjust the importance of the local values integrated into the curriculum to increase the spirit of nationalism (Putri \& Yuli, 2017; Yamin, 2017), and use inquiry-based history module in instilling nationalistic values to the students (Mujiyati et al., 2017).

The earlier research description showed that there are still no researchers focusing on the research discussed how two values can frame Indonesian and Islamic in one harmonious frame, encompassed nationalism and religious values simultaneously. This research focuses on examining how nationalistic and religious values are integrated into the instruction in Integrated Islamic School. Two essential values are because nationalistic and religious values will form the obedience of individuals towards their state and God that also become characteristic of Indonesian in which the country does not separate the state life and religious life. Integrated Islamic School became a focus of this research based on the consideration of this institution, which is a new model of this educational institution that previously has developed and has the appeal of broad society. In detail, the objectives of this study are; 1) Why is it important to instill nationalistic and religious values in students in integrated Islamic 
schools? 2) How do the teachers in the Integrated Islamic School integrate nationalistic and religious values in classroom learning?

The results of this study are expected to deliver the insight of how nationalistic and religious values developed in Islamic schools in Indonesia. The school principal also can utilize this finding in planning a learning program integrating nationalistic and religious values. Also, the teachers can render this finding as a model in implementing the strategy of value learning, particularly nationalistic and religious values.

\section{REVIEW OF LITERATURE}

\section{Character Education in the Islamic Education System}

Character education in the school becomes a discussion theme discussed by various groups. It is caused by the opinion of most parties, which states that the character education process still has not obtained the expected results. Various cases, incidents, and phenomena show that nation's generation has not yet had robust character, i.e., religious character, nationalism, independence, cooperation, and integrity. These five characters are the central values expected to be had by the future generation to build Indonesia into the country that the founding fathers had dreamed of. The enactment of the national education system of 2003 mentioned that national education purpose is to develop student's potential in order to be humans who believe and fear God Almighty, have a noble character, are healthy, knowledgeable, capable, creative, independent, and become democratic and responsible citizens (UU Sisdiknas of 2003). National education purpose is supposed to be a responsibility to all of the parties, i.e., education stakeholders, education leaders, education practitioners, and society in general. Formal educational institutions from pre-school to tertiary levels are responsible for achieving these national education purposes. Islamic educational institutions are one of the formal educational institutions in Indonesia that also become a channel to prepare student's character. Sutrisno and Suyatno (2015) stated that Islamic educational institutions either madrasa or Islamic school is an ideal form of educational institution in Indonesia because those are the institutions attempting to combine the advantages of modern schools and Islamic boarding schools. The advantage of Islamic boarding schools is that there are religious subjects supposed to be a foundation to form students' characters, while the advantage of public school is that general science is useful to equip the students in the mastery of science and technology. By these two advantages, it is expected that either madrasa or Islamic schools can prepare their students with the result that a generation with strong character also develops science and technology in order to be an activator in building the next civilization.

Islamic education is still receiving much criticism from various parties. Hidayat and Wijaya (2016) stated that there are at least three crises, namely a paradigmatic crisis, a crisis of vision and direction, and a development crisis. A paradigmatic crisis is manifested in the fact that Islamic education still becomes a dichotomic between general science and religion, a dichotomy between revelation, universe, and reason. The crisis of vision and direction is manifested in the fact that most of Islamic education is still not be able to formulate the vision and direction od their education, with the essence of Islamic educational purposes itself. Islamic educational institutions still render Islam itself as discussion objects and do not make Islam as the way of people's life. The development crisis is manifested in the fact that Islamic educational institutions, all this time, do not show the advancement. Islamic education is still not supported by sustainable research and development conducted by either individual, society, or government. As a result, the institutional management model and learning approach did not experience significant development. The existence of a crisis in the learning process and approach has made Islamic education lose its substance as an institution that 
teaches how to empower minds and thoughts. Islamic education has lost the spirit of inquiry, which means losing the enthusiasm for reading and researching, which used to be the central supremacy of Islamic education in the medieval, classical era. With the loss of the spirit of inquiry, teaching and learning activities in a madrasa, Islamic school, or Islamic boarding school become monotone, one-way, and less able to develop the method that train and empower students' ability. A further impact of this problem, Islamic schools, often associates with a backward institution and does not produce qualified graduates (Efendi, 2008).

Syahminan (2014) explained that Islamic education is expected to be an outstanding education that has an integral (integralism), humanistic, and pragmatic principle and is based on a strong culture. Integralistic means that Islamic education contains life components as a whole, which includes God, humans, and the universe. Integralistic education can form the people who have the integrity, obey God's will, merge with themselves, society, and nature. Humanistic education places humans as God's creatures who have specific characteristics. Humanistic education is expected to be able to place humans according to their nature as God's most noble creatures. Pragmatic education is education that places humans as living beings who have various needs to maintain their survival, such as physical and spiritual, physical and psychological, material, and spiritual needs. Pragmatic education will be able to form the students about the awareness of their life needs and able to be sensitive to human's problems. Education with strong cultural roots is education that does not leave historical roots. Education with strong cultural roots can form the students to have personalities, selfesteem, believe in themselves, and build the civilization based on their own culture, which is the legacy of the country's founders.

\section{The Role of Islamic School toward Character Education in Indonesia}

Besides public schools, there is much developed Islamic school under the Culture and Education Ministry. Islamic schools emerged from the notion of a part of the community with a religious background who want to open modern schools with religious studies as additional subjects. The main initiators in Islamic modernization education are Islamic modernist organizations such as Jami'at Khair, Al-Irsyad, and Muhammadiyah (Fathoni, 2005).

In subsequent developments, the establishment of Islamic schools became the inspiration for other organizations such as Nahdatul Ulama, the Islamic Union (Persatuan Islam), and the others. The schools established by these organizations are public schools which include religious lessons and add the Islamic name on the back. Islamic Kindergarten, Islamic Elementary School, Islamic Junior High School, Islamic Senior High School are institutional forms established by these organizations. In addition, some organizations use a specific name such as SD Muhammadiyah, SMP Maarif NU, SMA Al-Irsyad. Also, some schools use Arabic symbols, for example, Al-Falah Elementary School, Futuhiyah Middle School. Moreover, the most recent is the establishment of TKIT, SDIT, SMP IT, SMA IT with a full day school model, or Boarding School model (Fathoni, 2005).

Islamic schools in subsequent developments received enthusiastic responses from the wider community, especially those who were dissatisfied with public schools and madrasa. They consider that education in madrasa is not capable of equipping their alumni to master science and technology, while public schools are unable to equip their alumni to have a strong character foundation due to the lack of religious lessons. To cover the weaknesses of these two institutions, Islamic schools become an alternative for those who want to gain a balanced education model. 


\section{Integration of Nationalistic and Religious Values in Islamic Education}

The program of strengthening character education is the program made by the government in preparing generations with character. Character education is the various attempt carried out by school personnel, also carried out along with the parents and the society to help children and adolescents in order to have the character of caring, resolute, responsibility (Hendarman, 2017).

According to the Guidelines for strengthening the character education program (Penyusun, 2017), the implementation of PPK must be integrated. The implementation of national education, especially in primary and secondary schools, is developed and implemented by combining, connecting, and requiring various educational elements and is not be embedded and an additional program in the implementation of the educational process. The movement of PPK placed character education as a most profound dimension or core national education, so that character education becomes the implementation axis of primary and secondary education. PPK needs to integrate, deepen, broaden, and harmonize the various character education programs and activities that have been implemented until now. In this relationship, the integration can be the combination of classroom activities, out of classroom activities in the school, and out of school activities (society/community); the combination of intracurricullar activities, co-curricular, and extracurricular; the involvement of students simultaneously can be added and intensifying activities oriented to the development of student's character, the addition, and adjustment of teacher's primary duties, school-based management, and the function of school committee along with the need of PPK movement.

One of the essential values in strengthening character education program is a religious value. Religious values reflect the faith of God and religion and their belief, respect religious differences, uphold a tolerant attitude towards the practice of other religions and beliefs, live in harmony and peace with followers of other religions.

The value of religious character consists of the relation of three dimensions, namely the relationship between human and God, human to human, and human to the universe (environment). The value of character religion is shown in loving behavior and maintain the integrity of God's creation. Religious sub-value includes several criteria such as love peace, tolerance, the respectability of differences toward religion and belief, steadfastness, selfconfidence, cooperation between religions and beliefs, strong determination, self-confidence, cooperation among the specific religion followers and their belief, anti-bullying and violence, friendship, sincerity, not imposing a will, loving circumstances, and protecting a low-level and marginalized society.

Except for religious values, nationalistic values also become one of the central values in PPK. Nationalism values are essential to be instilled in the students because character values favorably impact on national resilience (Fuadi, 2020; Ibda, 2017). Nationalistic character values are traits of thinking, behaving, and acting that are showed by loyalty, sympathy, and high appreciation on language, physical environment, social, culture, economic, national politics, also placing the interest of nation and state above self-interest and group. Nationalistic sub-value is the appreciation of the nation's culture, nation's cultural wealth maintenance, willingness to sacrifice, eminence, and respecting diversities of culture, ethnicity, and religion, gaining the achievement, loving their state, nurture the environment, obeying the law, and discipline. 


\section{RESEARCH METHODS}

\section{Research design}

This design of research is qualitative research with a case study. Qualitative research produces descriptive data (Milinki, 2016). The case study approach is one of five approaches in the qualitative approach (Creswell, 2013; Silverman, 2015). In this case study, a sample magnitude does not become the primary measure (Boddy, 2016) because human beings can produce more data.

\section{Participant}

Research data resources were the teachers of primary and secondary schools in the Integrated Islamic School in the Yogyakarta region. Data resources were determined based on sampling purposive technique (Etikan, 2016; Gentles, Charles, Ploeg, \& McKibbon, 2015). The research subject of demographic illustration is explained in table 1.

Table 1. Research subject demography

\begin{tabular}{|c|c|c|c|c|c|}
\hline $\begin{array}{l}\text { Name } \\
\text { (initial) }\end{array}$ & $\begin{array}{l}\text { Education } \\
\text { level }\end{array}$ & Gender & Status & $\begin{array}{l}\text { Teaching } \\
\text { experience }\end{array}$ & School-level \\
\hline $\mathrm{Bn}$ & S1 (Bachelor) & Female & $\begin{array}{l}\text { Vice school } \\
\text { principal of } \\
\text { student service }\end{array}$ & 17 years & $\begin{array}{l}\text { SMP IT (Integrated Islamic } \\
\text { Junior High School) }\end{array}$ \\
\hline Is & S1 (Bachelor) & Female & $\begin{array}{l}\text { Craft and cultural } \\
\text { art teacher }\end{array}$ & 11 years & $\begin{array}{l}\text { SMA IT } \\
\text { (Integrated Islamic Senior } \\
\text { High School) }\end{array}$ \\
\hline $\mathrm{Jm}$ & S2 (Master) & Male & $\begin{array}{l}\text { Islamic education } \\
\text { teacher }\end{array}$ & 3.5 years & $\begin{array}{l}\text { SMP IT } \\
\text { (Integrated Islamic Junior } \\
\text { High School) }\end{array}$ \\
\hline Wak & S2 (Master) & Female & $\begin{array}{l}\text { Mathematics } \\
\text { teacher }\end{array}$ & 5 years & $\begin{array}{l}\text { SMA IT } \\
\text { (Integrated Islamic Senior } \\
\text { High School) }\end{array}$ \\
\hline Msnc & S1 (Bachelor) & Male & $\begin{array}{l}\text { Classroom } \\
\text { teacher }\end{array}$ & 18 years & $\begin{array}{l}\text { SD IT } \\
\text { (Integrated Islamic Primary } \\
\text { School) }\end{array}$ \\
\hline $\mathrm{Al}$ & S1 (Bachelor) & Male & $\begin{array}{l}\text { Classroom } \\
\text { teacher }\end{array}$ & 9 years & $\begin{array}{l}\text { SMP IT } \\
\text { (Integrated Islamic Junior } \\
\text { High School) }\end{array}$ \\
\hline
\end{tabular}

\section{Data Collection}

Research data was collected through interviews and documentation. The interview is conducted by using a semi-structured interview (Flick, 2018; Sutton \& Austin, 2015; Tracy, 2019). In conducting interviews, researchers were guided by research guidelines in the form of questions developed from the central research questions (Creswell, 2008; Creswell, 2013b). The documentation was conducted by collecting the school's documents consisted of the school's vision and mission, curriculum, syllabus, daily learning plan, and textbooks to be student's learning resources in the class. Research data validity was measured through data saturation (Fusch \& Ness, 2015). The researchers conducted triangulation from various resources, and the data would be considered adequate if no new data were found (Saunders et al., 2018).

\section{Data Analysis}

Data collected was analyzed by inductive interactive qualitative data analysis of Miles and Huberman (1994), including four steps; data collection, data reduction, data display, and 
conclusion withdrawal. The results of data analysis produced themes (Houghton, Murphy, Shaw, \& Casey, 2015; Castleberry \& Nolen, 2018) that aimed to answer the formulation of the problem.

\section{RESULTS AND DISCUSSION}

Data presented in this study bases on two formulations of the problems that are answered in the study. Specific codes further analyze the data collection. Researchers group the same code into themes. Of the six themes found, the researchers grouped them according to categories in answering the formulations of the problems.

\section{Aim to Integrate Nationalistic and Religious Values in the Integrated Islamic School}

Based on the data analysis collected in the research field, either from an interview or document collection, it found the important themes about the aim to integrate nationalistic and religious values in Integrated Islamic School, namely an ideal Indonesian human concept. According to the research subject, the primary purpose of instilling nationalistic and religious values in the educational process in the schools is to prepare an ideal Indonesian human, namely the human beings who have a full and balanced nationalistic and religious soul. These themes include four sub-themes such as nationalism and religiosity as an obedient indicator in religion; nationalism and religiosity as an obligation of citizenship; Integral human concept; not being split-personality; to be the Muslims of Indonesia and Indonesian's Muslim.

\section{Nationalism and Religiosity as an Obedient Indicator in Religion}

The integration of nationalistic and religious values is an indicator of Muslims who obey their religion due to Islam itself, the love of the state as a part of God's order. Through the interview, Bn stated that:

Nationalism and religiosity is a component which can not be separated. Both are the unity that all Indonesian must-have. Nationalism or loving their state is evidence that someone obeys their religion (Interview with Bn; February 2020).

Wak, A mathematics teacher in integrated Islamic senior high school, stated the same opinion. Through the interview, Wak mentioned that:

To build all of the student's character and attitude must be instilled a religious attitude. This religious attitude must be combined with nationalistic value to instill strong character of nationalists in students themselves. The spirit of Islam is combined with loving their state (Interview with Wak; February 2020).

Nationalism and religiosity is the combination of two values with an indicator in each. Nationalistic value is a loyalty of the citizenships toward the state of Republic Indonesia. Bn from his interview mentioned that nationalistic in SIT has the indicator as follow:

Among the indicators, instilling the value of nationalism in SIT is the activities of nationalism and patriotism that aims to grow the love of the state and practice the attitude of nationalism and patriotism in daily life. Several commemorations are the commemoration of independence day's of Indonesia, heroes' day, Kartini's day, national education's day, youth pledge, and other big day's commemorations held to love the nation and Indonesia state. Besides, to know and exemplify independence's heroes, display the portrait of national heroes except for the portrait of the president and vice president also the national emblem of Indonesia in the existing rooms (Interview with Bn; February 2020). 


\section{Nationalism and Religiosity as a Citizen's Obligation}

Except for the obedience indicator religion, nationalism and religiosity is a loyalty of the citizenships toward their state. A good citizen is the citizens who love their state and obey their God because of the national principle of Indonesia that is called Pancasila. In the first article of Pancasila, it begins with the belief in the one and only God. Bn explained that:

Pancasila begins with deity, which means that every citizen who wants to struggle for the sake of the nation and state of Indonesia is the person who obeys their religion. That attitude is what was exemplified by national independence heroes (Interview with Bn; February 2020).

\section{Bn asserted that:}

Because religious values become the spirit for children as the basis for stepping, learning, and behaving as human beings who live socially. The value nationalism, since we live in a country, recognizes and is involved and obey the state rules. Our supreme state rule that has been agreed upon is Pancasila (Interview with Bn; February 2020).

Im, an Islamic education teacher in junior high school, agreed on the same opinion. Trough the interview, Jm mentioned that:

The soul of nationalism is the form of love toward Indonesia state that is a basic need for the next generations because genetically, they are born that earth. Meanwhile, religious value is the main foundation for all of the Muslims in their activities. It is believed that religious value (in Islam, usually called akhlak/moral/adab) occupied the highest values and higher than the primary worship called shalat (praying) (Interview with Jm; February 2020).

The combination of the value of deity as a life guide and the state as a nation's manager becomes a right, as the founding father made religion as the spirit of the nation. We must believe the result of an attempt (in Arabic called Ijtihad) as a solution and a beautiful middle way in harmony. If we do not match those traits, there are many losses such as schism, mutual distrust, character decline, and many other things (Interview with Al; February 2020).

The spirit of religiosity in Indonesia exists in the first article of Pancasila, namely Belief in the one and only God and the opening of UUD 45. Furthermore, information and technology education as one of the facilities in Islamic education takes this issue as the spirit of the nation by holding on religious value (Interview with Al; February 2020).

\section{The Concept of Integral Human, Not Split-Personality}

An integral human is a human being who combines several characteristics in which the unity of several characteristics makes him a complete human figure because several complementary aspects form humans; soul-body, world-hereafter, body-spirit. In the context of nationalism and religiosity, integral means unity as good citizenship and obedient God servant. Through the interview, Bn explained that:

Being nationalist and religious is an ideal combination that every citizen must-have. Instilling both values must begin from school (interview with; February 2020).

Being nationalist and religious is a manifestation indicator of the ideal society. All of the people must have religiosity toward their God to gain happiness. Nationalistic value is a manifestation from understanding a religion implemented in the nation and state life (Interview with Bn' February 2020). 
Is strengthening Bn's notion stated that:

Humans who are integrated with their circumstances are cultured humans who understand and interact actively in society while still adhering to Islamic principles, propriety, and not disobeying the law. Humans who develop their knowledge and technology are because they are aware that the success of human is not only thinking about the life hereafter but also aware and think of the world life. Even they are able to compete at the national and international levels (Interview with Is; February 2020).

The integral human being is an ideal human to be achieved in the learning process in an Integrated Islamic school. Jm mentioned that:

The portrait of the ideal human beings, according to SIT, is the prophet Muhammad SAW and depicted in seven graduate competency standards, namely straight faith, and right worship, good moral and able to keep lust, discipline, and good time management, healthy body, broad knowledge, have income, structured in any business, a spirit in any activities, a benefit for the circumstances (Interview with Jm; February 2020).

\section{Indonesian's Muslims and Muslim Indonesian}

Indonesia is a country with the largest Muslim in the world. Besides, the majority of Indonesian are Muslim. These two facts made Indonesia and Islam can be separated. Therefore, it is known as Indonesian's Muslim, the Muslim who is holding on Indonesia's character, and Muslim Indonesian is Indonesian who always keep their Muslim identity. The name of nationalistic and religious values in SIT is one of the manifestations in forming Indonesian Muslim generations and Muslim Indonesian. Through the interview, Is stated that:

Because religious value becomes a spirit for children as a basis for implementing learning and behaving as human beings in social life. Nationalistic values, because we are living in the state, admit and involve, and also comply with state rules. The highest state rules that have been agreed are Pancasila (Interview with Is; February 2020).

Is' result of the interview showed that nationalistic and religious values are essential values that must be instilled in the children. Instilling both values in a balancing way will equip the citizen who is proud of their identity, Indonesian and Islamic identity. This notion strengthened by Is in which both values need to be a character priority must be instilled through the learning process in schools. Jm said:

We need strongly equipping the students both abovementioned values because the challenges to be faced by the nation's society is more complex. In addition, national knowledge as a doctrine of Indonesias values adhered and manifested as national identity. Meanwhile, the religious value of the students is being ruled out by existing of technology impact, ideology, other nation's cultures that are not in line with Islamic values (Interview with Jm; February 2020).

\section{The Strategy of Instilling Nationalistic and Religious Character in Integrated Islamic School} Nationalistic and religious values in Integrated Islamic schools are instilled in students in many ways. Through the data analysis, there are three main traits conducted by Integrated Islamic schools in instilling nationalistic and religious values for the students; integration in curriculum, co-curriculum, and extracurricular; value internalization, and habituating the values. 
Value Integration in Curriculum, Co-Curriculum, and Extracurricular

Instilling nationalistic and religious value Integrated Islamic school conducted by incorporating these two values into curriculum structure in SIT, co-curriculum in the form of structured activities and assignments outside the classroom, and extracurricular activities which are implemented as additional lessons outside formal class hours. Ai, a classroom teacher in Integrated Islamic junior high school, stated that:

Not separating the two values (nationalism and religiosity) included in the curriculum, such as intracullicular, co-curricular, and extracurricular. Also included in school curriculum such as civic education, social science education, Al-Qur'an, Hadith for religion (Interview with MSNC; February 2020).

In addition, nationalistic and religious values are included in co-curricular in the form of activities and personal structured assignments so that student's competency can be achieved. Ai continues:

The activities are included in extracuriculler, such as scout, choir, and others. To conduct a big Islamic day's commemoration and other religious day's commemoration is a form of tolerance. Then, instilling the values of love and defense to their nation and state in many activities like discussion, literacy, drama, poster, etc. To instill the values of kind/religiosity conducts in all school activities. To conduct the ceremony and other activities is that related to nationalism and religiosity (Interview with Al; February 2020).

\section{Internalization of Nationalistic and Religious Values}

Internalization deepens and appreciates the teaching, doctrine, and values. It believes and aware of doctrine truth or value manifested in attitudes and behavior. Therefore, value internalization essentially is a process to instill something that is values manifested process that will form a student's mindset in looking for a meaning of the reality of the experience. In an Integrated Islamic school, value internalization becomes an essential strategy in instilling nationalistic and religious value to students. Value internalization is conducted in many ways. Wak, a mathematics teacher, mentioned that:

Values internalization is conducted in morning assembly once a week and singing national anthem every day. Conducting commemoration national big days like Indonesian Independence Celebration, youth pledge, national education day, etc. (Interview with Wak; February 2020).

In line with Wak's explanation, Is (craft and cultural art teacher in Integrated Islamic school) stated that nationalistic values in integrated school are instilled through the activities as follows:

The values contain singing the national anthem, memorizing and broadcasting national anthem, carrying out the ceremony to grow nationalism, loving nation' creation, maintaining the national culture of Indonesia, addressing diversities, religion and ethnic wisely, abstaining from and rejecting vandalism, being proud of Indonesia's nation, respecting and understanding the figures of founding fathers as a form of love for the efforts of the heroes (Interview with Is; February 2020).

\section{Habituated Nationalistic and Religious Values in the School Culture}

Habituating is the formation process of attitude and behavior relatively permanent and automatic through the learning process recurred that is conducted either simultaneously or individually. By habituating the values, the students do not only know and understand the 
values, but they used to live with certain values. Besides internalization, habituated values also become a crucial strategy to instill nationalistic and religious values to students in Integrated Islamic schools. Habituating is conducting daily, weekly, monthly, annual activities. Through the interview, Bn explained that:

Religious value in SIT is instilled through activities as follows: first, Dhuha prayer and reciting the Holy Qur'an together then is continued by reading Du'a. These activities are routinely conducted and are required to be implemented by academics and become routine activities conducted by students every morning at 07-00-07-30 WIB. In these activities, Dhuha prayer is required to do, recite a Holy Qur'an together lead by students on duty, and finish by Du'a. Second, instilling character "a million message": spirit, honesty, responsibility, caring, and polite that is conducted through daily, weekly, monthly activities. Third, everyday Pesantren Tahfidz (Islamic boarding school focused on memorizing Al-Qur'an). This program conducts every day. This term uses to call the activity of memorizing Al-Qur'an intended for the students who tend to memorize AlQur'an and other related to abilities. Therefore, they can memorize Al-Qur'an minimally 7-10 Juz. Fourth, Mabit (night for building faith and piety) and Tadabbur (contemplating a meaning deeply). This program is conducted every month in which on the scheduled day, every student must stay overnight (Mabit) in a specific place (usually Mosque in Yogyakarta area) to read Al-Qur'an and memorizing all day long, also study about the meaning of Al-Qur'an (interview with Bn; February 2020).

Balanced with the habituating religious values carried out in various routine school activities, as well, either nationalistic values are. Al explained that:

Instilling the values of love and defense towards state and nation with various activities routinely like discussion, literacy, drama, and making a poster (including the messages of nationalism) (Interview with Al; February 2020).

\section{Discussion}

This research aims to answer two questions; first, why nationalistic and religious values are essential to be integrated with the learning process in Integrated Islamic schools. Second, how the strategy of instilling those two values in school. Based on data analysis, there are two findings: first, integration of nationalism and religiosity in Integrated Islamic school is carried out based on the ideal Indonesian human concept as aspired by the founder of Integrated Islamic school. Second, both values are instilled to students through three traits; integration in curriculum, co-curriculum, and extracurricular, internalization of nationalistic and religious values, and habituating the values into school culture. These two findings are adequately discussed in this article.

First, an ideal Indonesian human concept in the world of views of school founders becomes the main excuse to integrated nationalistic and religious values in Integrated Islamic school. According to the founders, an ideal Indonesian human is the human being who humans who fear the Almighty God and are obedient in carrying out their obligations as citizens. Religious values reflect the faith toward God and belief embraced, respecting the diversity of religion, upholding a tolerant attitude towards the implementation of religious worship and other beliefs, live in harmony and peace with other religious followers (Tim Penyusun, 2017). Nationalistic values are the ways of thinking, behaving, and doing that are shown a loyalty, caring, and highest achievement on language, physical environment, social, culture, economic, and political nation, and placing the interests of state and nation above self 
and group interest. The formation of humans with the intended indicators is expected to be the next generation to realize the aspirations of the Indonesian citizens.

An ideal Indonesian human concept is also in line with the purpose of national education included in the Law of the National Education System Number 20 of 2003 that stated that the purpose of national education is to develop student's potential in order to be a human in faith and taqwa toward The One Almighty God, have a noble character, healthy, knowledgeable, competent, creative, independent, and become democratic and responsible citizens. This concept is also a part of the manifestation of national curriculum implementation validated until this time. In curriculum 2013, the learning process that occurred in the school must contribute to core competency 1 (KI-1) about spiritual competency and core competency 2 (KI-2) about social competency. Spiritual competency is someone's respect and appreciation toward religion's teaching he adhered to. Social competency is someone's respect and appreciation toward honesty, discipline, responsibility, caring, polite, self-confidence in interacting with others. The achievement of two competencies and added by knowledge competency (KI-3) dan skill competency (KI-4) make the alumni of an educational institution in Indonesia become the human beings who develop as a whole and in the balance between body-spirit, body-spirit, cognitive-affective-psychomotor. The results of the research generally in line with the research of Suharto (2017), which stated that the school occurs under NKRI demand to have a role strategically in strengthening moderate Islam, becoming the main character for Muslims in Indonesia. Islamic education held by Islamic educational institution with typical Indonesian character become an agent in the teaching of moderate Islam Indonesia to the students.

Second, nationalistic and religious in SIT instilled to students through three traits; internalization of nationalistic and religious values; habitual activity of nationalistic and religious values in the school culture. Integration in the curriculum is carried out by making the nationalistic and religious values as core competency formation. Besides, integration in co-curricular is carried out by inserting nationalistic and religious values into activities that support the formal curriculum and student's structured assignments. Integration in extracurricular is carried out by inserting nationalistic and religious values in school. In SIT, extracurricular activities used to develop nationalistic values are scout. In comparison, religious values are widely instilled in extracurricular activities like reciting Holy Qur'an, memorizing Holy Qur'an, and others.

This result is in accordance with the explanation, which states that in order for the cultivation of values to be successful if it is carried out through a structured program in schools (Suyatno et al., 2019; Raihani, 2018). Curriculum, co-curriculum, and extracurricular must simultaneously support the instilling of nationalistic and religious values to students. The second trait is that the internalization of nationalistic and religious values is conducted along upon morning assembly held every Monday, singing national anthem every day, commemorating big national days such as Indonesia's anniversary, youth pledge, and national education days. Through national big days' commemoration, the school attempts to internalize nationalistic values to the students. While the internalization of religious values is also instilled through big Islamic days, Tusiyah (a term used among the Muslim community in Indonesia) attended by school principal and teachers, Mabit (night for building faith and piety), and other activities. Through these activities, schools attempt to internalize religious values to students.

Third, the trait conducted by SIT in integrating nationalistic and religious values to students is through habituated activities in school culture. Habituating is an action conducted repeatedly is to habituate an individual to stand on attitude, behave, and think properly. Habituating nationalistic and religious values in SIT is integrated into school culture such as 
everyday routine activities like Dhuha prayer, reciting Holy Qur'an and Pesantren Tahfidz (Islamic boarding school focused on memorizing Al-Qur'an), as well as "a million messages" activities consisted of the messages of honesty, spirit, responsibility, and polite. In addition, there are also monthly routine activities such as Mabit and Tadabbur Al-Qur'an. While habituating nationalistic values is carried out tributing Indonesia's flag in ceremony and other state symbols displayed in the classroom and school's strategic places. These findings are generally in line with the finding of Marini (2017) and Ma arif and Rofiq (2018) stated that habituating the values is conducted in not only the classroom but also school culture simultaneously. To support this success, Muttaqin and Raharjo (2018) explained that school requires to establish cooperation among parents and make the teacher role model for students. In this case, the teachers' role is huge because teachers have a suitable competency that will determine the instilling of values toward students (Nurdin, 2017). Habituated activities through school culture are formed in routine activities, occur spontaneously, conditional, the exemplary for school residents. The activities carried outside learning hours are to strengthen character building that is suitable for the situation, condition, existence of the facilities in the school.

\section{CONCLUSION}

The purpose of nationalistic and religious value integration in integrated Islamic school of Yogyakarta occurs in ideal Indonesian human concept, human beings who obey as a servant their God and as citizens. To values become essential components to shape future Indonesia's next generation. Three strategies apply the integration of nationalistic and religious values; integration in curriculum, co-curriculum, and extracurricular, which includes value internalization and value instilling in daily life. The research findings recommend the importance of integrating nationalistic and religious values in the character educational process in school because both values are essential to prepare future Indonesia's next generations. In order, the process of instilling values is successful, so that nationalistic and religious values must be inserted into a formal curriculum, co-curriculum, and extracurricular, along with internalizing and habituating values in student's daily life. This research is limited by data research that was only collected from teacher interviews and documentation related to school so that the process only occurs by triangulation of data resources. The next research requires using triangulation as the technique of data collection along with various methods such as interviews, observation, and documentation.

\section{ACKNOWLEDGMENT}

Researchers would like to thank the sources of research data from the Yogyakarta Region Integrated Islamic School who were willing to conduct the interviews. Also, thank Universitas Alma Ata Yogyakarta and Universitas Ahmad Dahlan for providing the opportunity and support for the implementation of research collaboration between these two institutions.

\section{REFERENCES}

Abdurrahim. (2016). The Islamic Boarding School is always connected to the institution which produces the rebellions behavior and building radicalism in many Muslim countries, $i$. e Pakistan, Afghanistan, and Indonesia. The radicalism. 2(1).

Susanto, A. \& Suntoro, Y. N. (2018). Internalisasi Nilai-Nilai Nasionalisme Dalam Pembelajaran PPKn. Jurnal.Fkip.Unila.Ac.Id.

Alkatiri, W. (2017). A Twin Pregnancy: Islam and Nationalism in Indonesia. Istiqro, 15(01), 231-276. http://istiqro.kemenag.go.id/index.php/istiqro/article/view/78 
Aspinall, E. (2016). The New Nationalism in Indonesia. Asia and the Pacific Policy Studies, 3(1), 72-82. https://doi.org/10.1002/app5.111

Boddy, C. R. (2016). Sample size for qualitative research. Qualitative Market Research: An International Journal.

Bourchier, D. M. (2019). Two Decades of Ideological Contestation in Indonesia: From Democratic Cosmopolitanism to Religious Nationalism. Journal of Contemporary Asia, 49(5), 713-733. https://doi.org/10.1080/00472336.2019.1590620

Castleberry, A., \& Nolen, A. (2018). Thematic analysis of qualitative research data: Is it as easy as it sounds?. Currents in Pharmacy Teaching and Learning, 10(6), 807-815.

Creswell, J. W. (2008). Educational research: Planning, conducting, and evaluating quantitative and qualitative research (3rd ed.). Pearson Prentice Hall.

Creswell, J. W. (2013a). Qualitative inquiry and research design: Choosing among five approaches (C. S. Thousand Oaks (ed.); (3rd ed.)).

Creswell, J. W. (2013b). Qualitative inquiry and research design: Choosing among five approaches (3rd ed.). Sage.

Efendi, A. (2008). Peran Strategis Lembaga Pendidikan Berbasis Islam di Indonesia. ElTarbawi, 1(1), 1-11. https://doi.org/10.20885/tarbawi.vol1.iss1.art1

Etikan, I. (2016). Comparison of Convenience Sampling and Purposive Sampling. American Journal of Theoretical and Applied Statistics, 5(1), 1. https://doi.org/10.11648/j.ajtas.20160501.11

Fathoni, M. K. (2005). "Pendidikan Islam dan Pendidikan Nasional (Paradigma Baru)." Departemen Agama RI: Direktorat Kelembagaan Agama Islam.

Flick, U. (2018). Designing qualitative research. Sage.

Fuadi, A. (2020). Implementasi Total Quality Managemen di SMPIT Abu Bakar Yogyakarta dan Implikasinya Terhadap Prestasi Sekolah. XI(1), 1-10.

Fusch, P. I., \& Ness, L. R. (2015). Are we there yet? Data saturation in qualitative research. The Qualitative Report, 20(9), 1408.

Gentles, S. J., Charles, C., Ploeg, J., \& McKibbon, K. A. (2015). Sampling in qualitative research: Insights from an overview of the methods literature. The Qualitative Report, 20(11), 1772-1789.

Ibda. (2017). Konsep Hubbul Wathan Minal Iman Dalam Pendidikan Islam Sebagai Ruh Nasionalisme. International Journal Ihya' 'Ulum Al-Din, 19(1), 1. https://doi.org/10.21580/ihya.18.1.1740

Hendarman, et al. (2017). Konesp dan Pedoman Penguatan Pendidikan Karakter. Kemendikbud, 53(9), 1689-1699. https://doi.org/10.1017/CBO9781107415324.004

Hidayat, R., \& Wijaya, C. (2016). Ilmu pendidikan Islam: menuntun arah pendidikan Islam di Indonesia.

Houghton, C., Murphy, K., Shaw, D., \& Casey, D. (2015). Qualitative case study data analysis: An example from practice. Nurse Researcher, 22(5).

Ismawati, E. (2018). Nationalism in Indonesian Literature as Active Learning Material. International Journal of Active Learning, 3(1), 33-48. https://doi.org/https://doi.org/10.15294/ijal.v3i1.10883

Ma`arif, M. A., \& Rofiq, M. H. (2018). The Role of Islamic Education Teachers in Improving the Character of Nationalism in Boarding School. EDUKASI: Jurnal Pendidikan Islam, 6(1), 064-078. https://doi.org/10.5281/EDUKASI.V6I1.323

Marini, A.. (2017). Integration of Character Values in School Culture at Elementary Schools in Jakarta, Indonesia. Journal of Arts and Humanities, 6(5), 21. https://doi.org/10.18533/journal.v6i5.1171

Miles, M. B., \& Huberman, M. (1994). Qualitative Data Analysis: An Expended Sourcebook. 


\section{Sage.}

Milinki, A. K. (2016). Cases in qualitative research: Research reports for discussion and evaluation. Routledge.

Mujiyati, N., Warto, W., \& Agung, L. (2017). The Strategies to Improve Social Solidarity of Senior High School Students through History Module Based on Problems. Journal of $\begin{array}{llll}\text { Education and Learning } & \text { (EduLearn), }\end{array}$ https://doi.org/10.11591/edulearn.v11i2.5833

Muttaqin, M. F., \& Raharjo, T. J. (2018). The Implementation Main Values of Character Education Reinforcement in Elementary School. Journal of Primary Education, 7(1), 103112.

Muzayanah, U. (2017). the Role of the Islamic Education Subject and Local Tradition in Strengthening Nationalism of the Border Society (Study in Temajuk Village Sambas Regency of West Borneo). Analisa: Journal of Social Science and Religion, 2(01), 41. https://doi.org/10.18784/analisa.v2i01.426

Nurdin, E. S. (2015). The Policies on Civic Education in Developing National Character in Indonesia. International Education Studies, 8(8), 199-209. https://doi.org/10.5539/ies.v8n8p199

Nurdin, E. S. (2017). Civic Education policies: Their effect on university students' spirit of nationalism and patriotism. Citizenship, Social and Economics Education, 16(1), 69-82. https://doi.org/10.1177/2047173416688039

Penyusun., T. (2017). Konsep dan pedoman penguatan pendidikan karakter. Pusat analisis dan sinkronisasi kebijakan sekretariat jendral kementerian pendidikan dan kebudayaan.

Putri, N. A., \& Yuli, K. S. P. (2017). The Implementation of Storytelling Method for History Education to Develop Nationalism Attitudes of Early Childhood in Handayani Brebes Kindergarten. Early Childhood Education Papers ( Belia ), 6(2), 69-73.

Raihani, R. (2018). Education for multicultural citizens in Indonesia: policies and practices. Compare, 48(6), 992-1009. https://doi.org/10.1080/03057925.2017.1399250

Silalahi, R. \& Yuwono, U. (2016). Research in social sciences and technology. Research in Social Sciences and Technology, 2(3), 58-57. http://www.ressat.org/index.php/ressat/article/view/329

Saunders, B., Sim, J., Kingstone, T., Baker, S., Waterfield, J., Bartlam, B., ... \& Jinks, C. (2018). Saturation in qualitative research: exploring its conceptualization and operationalization. Quality \& Quantity, 52(4), 1893-1907.

Silverman, D. (2015). Interpreting qualitative data. Sage.

Studies, S. (2019). Journal of Social Studies Education Research SosyalBilgilerĔgitimiAraştırmalarıDergisi. 10(2), 224-242.

Suharto, T. (2017). Indonesianisasi Islam: Penguatan Islam Moderat dalam Lembaga Pendidikan Islam di Indonesia. Al-Tahrir: Jurnal Pemikiran Islam, 17(1), 155. https://doi.org/10.21154/altahrir.v17i1.803

Sulistiyono, S. T. (2018). The Importance of Indonesia's Nationalism Revitalization in the Globalization Era: A Historical Perspective. Journal of Maritime Studies and National Integration, 2(1), 1. https://doi.org/10.14710/jmsni.v2i1.1684

Supratno, H. (2019). Multicultural Education for Cultivating Nationalism and Preventing Radicalism of Santri in Pesantren. Research on Humanities and Social Sciences, 9(20), 34. https://doi.org/10.7176/rhss/9-20-03

Sutrisno \& Suyatno. (2015). Pendidikan Islam di era peradaban modern. Prenada Media.

Sutton, J., \& Austin, Z. (2015). Qualitative research: Data collection, analysis, and management. The Canadian Journal of Hospital Pharmacy, 68(3), 226.

Suyatno., Jumintono., Pambudi, D.I., Mardati, A. \& Wantini. (2019). Strategy of Values 
Education In Indonesian Education System. International Journal of Instruction, 12(1), 607-624.

Syahminan. (2014). MODERNISASI SISTEM PENDIDIKAN ISLAM DI INDONESIA PADA ABAD 21. Ilmiah Peuradeun, II(2), 287-300. https://journal.scadindependent.org/index.php/jipeuradeun/article/view/35

Thoriquttyas, T., \& Rohmawati, N. (2017). Amplifying The Character Education And The Multiculturalism For a Nationalism Building. 1-12.

Tracy, S. J. (2019). Qualitative research methods: Collecting evidence, crafting analysis, communicating impact. John Wiley \& Sons.

Yamin, M. (2017). Integrating The Local Wisdom Values into The National Curriculum to Create the Nationalism Strength. Journal of Education and Practice, 8(33), 47-53. http://eprints.ulm.ac.id/3500/1/Integrating The Local Wisdom Values into The National Curriculum to Create the Nationalism Strength.pdf 